Original Research

\title{
Effects of Biochar and Sulfate Amendment on Plant Physiological Characteristics, Soil Properties and Sulfur Phytoavailability of Corn in Calcids Soil
}

\author{
Baowei Zhao*, Tao Zhang \\ School of Environmental and Municipal Engineering, Lanzhou Jiaotong University, Lanzhou 730070, China
}

Received: 3 August 2020

Accepted: 31 October 2020

\begin{abstract}
Although sulfur is an indispensable element for plants, its availability to plants in the presence of biochar is unclear. The effects of dairy manure biochar at the rate of $0,0.5,1,2$, and $5 \%$ on plant physiological characteristics, soil properties and sulfur phytoavailability in corn (Zea mays L.)-Calcids soil system were investigated using pot experiments with sulfate amendment at low, moderate and high level (0, 50 and $100 \mathrm{mg} \mathrm{S} \mathrm{kg}^{-1}$ soil). It was found that the plant height, fresh and dry weight, and chlorophyll content were significantly improved with the biochar addition rate increasing from 0 to $2 \%$ while largely decreased with the rate increasing from $2 \%$ to $5 \%$. The moderate level of sulfate amendment favored the corn biomass and chlorophyll content. The $\mathrm{pH}$ values of soil were significantly increased with increasing biochar addition rate, reaching about 8.50 at the rate of $5 \%$. The catalase, urease and sucrase activity in soil increased significantly with the biochar addition from 0 to $2 \%$ but largely decreased with the rate increasing from $2 \%$ to $5 \%$. Too high $\mathrm{pH}$ values due to $5 \%$ biochar addition resulted in the inhibitory effects on plant growth and microorganism activity in soil. Biochar addition at low rates $(<2 \%)$ and sulfate amendment at high level improved sulfur content in leaves and roots. The decreases of inorganic sulfur and total sulfur contents in soil with biochar addition rates significantly responded to the accumulation of sulfur in leaves and roots. The results show that co-application of biochar and sulfate with proper amount could improve the growth and sulfur phytoavailability of plant in calcareous soil.
\end{abstract}

Keywords: biochar, Calcids soil, sulfur, phytoavailability, corn

*e-mail: zhbw2001@sina.com 


\section{Introduction}

Sulfur plays a vital role in the processes of plant growth, including regulation, detoxification, and defense and stress resistance, and it is an important factor affecting plant quality $[1,2]$. According to statistics, more than 70 countries and regions worldwide have soils that are deficient in sulfur or have potential sulfur deficiency, which will ultimately result in huge losses in agricultural production. Therefore, increasing attention is paid to studies of sulfur nutrition [3-5].

Biochar is produced by pyrolysis and carbonization of waste biomass under oxygen-limited conditions [6]. It would be a promising alternative as soil amendment to sequestrate carbon, reduce greenhouse gas emission, improve soil fertility and crop growth, which attracts worldwide interest [7]. Although a few researchers have indicated that there could be organic (PAHs, low molecular weight organic acids and phenols, etc.) and inorganic (heavy metals) pollutants in biochars, which could pose the potential phytotoxic effects and environmental risk [8-15], the risk of pollutants in biochars could be reduced through optimizing pyrolysis conditions and removing pollutants before their large-scale agronomic application [8-14]. It has been shown that biochar amendment can facilitate the plant growth due to its effects on phytoavailability of the indispensable nutrients (e.g. nitrogen, phosphorous and potassium) in soil [14-18]. Biochar influences the processes of nitrogen conversion and thus influences the contents of total and available nitrogen in soil [7]. Biochar can significantly affect the content of phosphorous in soil and enhance plant growth [15, 19-21], through increasing the release of $\mathrm{P}$ from biochar and improving the physical and chemical properties of soil, such as improving in $\mathrm{pH}$ value, soil structure and cation exchange capacity (CEC), and reduction of phosphorous leaching [20, 22]. It has been shown that biochar can significantly increase the content of available potassium in the soil, in which the increment depended upon the biochar application rates $[17,23]$. However, there are few reports on sulfur phytoavailability in the presence of biochar [24], though sulfur is an indispensable element and the needed quantity for plant is only less than those of nitrogen, phosphorous and potassium.

Recently, a few references reported significant effects of co-application of biochar and inorganic fertilizer on soil properties and crop yield [23, 25-30]. Co-application of biochars and chemical fertilizer in soil improved wheat productivity and nitrogen uptake, where the increment was the highest in manure biochars, and it is recommended to use manure biochar alone or in combination with chemical fertilizer for immediate crop benefits [30]. Acacia (Acacia spp.) biochar amendment with nitrogen fertilizer significantly increased soil fertility and barley yield, and the highest yield, chlorophyll content, number of tillers and nutrient accumulation were observed from the compost- biochar soil amendment by nitrogen fertilizer [25, 26]. The interaction between rice husk biochar and inorganic nitrogen fertilizer significantly enhanced rice yield and yield components compared to the control, while enhancing soil nutrient availability and minimizing nitrate leaching [29]. Lusiba et al. reported a significant interaction between eucalyptus biochar and phosphorous fertilizer on the soil physical and chemical properties and chickpea yield [28]. Liu et al. also found that the addition of biochar and phosphorous fertilizer showed more positive effects on the promotion of growth and nutrient uptake of L. multiflorum [23]. A synergistic effect of maize-cob residue biochar and inorganic fertilizer (nitrogen: phosphorous: potassium $=15: 15: 15$ ) on the growth of maize in Alfisol soil with a field study was found by Faloye et al. [27], where the combined application resulted in an additional contribution of $11.4 \%$ and $16.5 \%$ for grain and biomass yields.

Therefore, the co-application of biochar and inorganic fertilizer could be a sustainable and environmentally friendly technology for the improvement of soil fertility and crop yield. However, there is no information on the co-application effect of biochar and sulfur fertilizer on soil properties and crop performance in agricultural soils. In addition, most of the previous results concerning the enhancement effects of biochar and fertilizer on soil property and crop growth were obtained in acidic soils with $\mathrm{pH}$ values less than 5 [23, 25-29]. Our previous studies show that the effect of biochar on soil properties and plant growth in alkaline soils (generally with high $\mathrm{pH}$ ) values [31, 32] could be quite different from those in acidic soils. The amendment of biochar even at a low rate into the soil could result in an exorbitant soil $\mathrm{pH}$ value and thus inhibit plant growth. So, in this paper, dairy manure biochar was prepared, and the effects of biochar and exogenous sulfate on the quality of corn, soil properties, and sulfur availability in a Calcids soil (calcareous soil) were investigated using pot experiments. The results could provide implications for the co-application of biochar and sulfate fertilizer in increasing soil efficiency and plant growth.

\section{Materials and Methods}

\section{Materials}

Dairy manure was collected from a cattle farm in Lanzhou City, China. After drying and grinding, the raw material was passed through a 40-mesh sieve. The debris was placed into a crucible and compacted. Then the crucible was covered with a lid and placed into a muffle furnace (SX2, Shanghai Yuejin Medical Equipment Factory) at $300^{\circ} \mathrm{C}$ under limited oxygen condition to ensure carbonization for $6 \mathrm{~h}$. After the crucible cooled to room temperature, the obtained char was passed through a 60 -mesh sieve, and stored 
Table 1. Basic physical and chemical properties of biochar and soil.

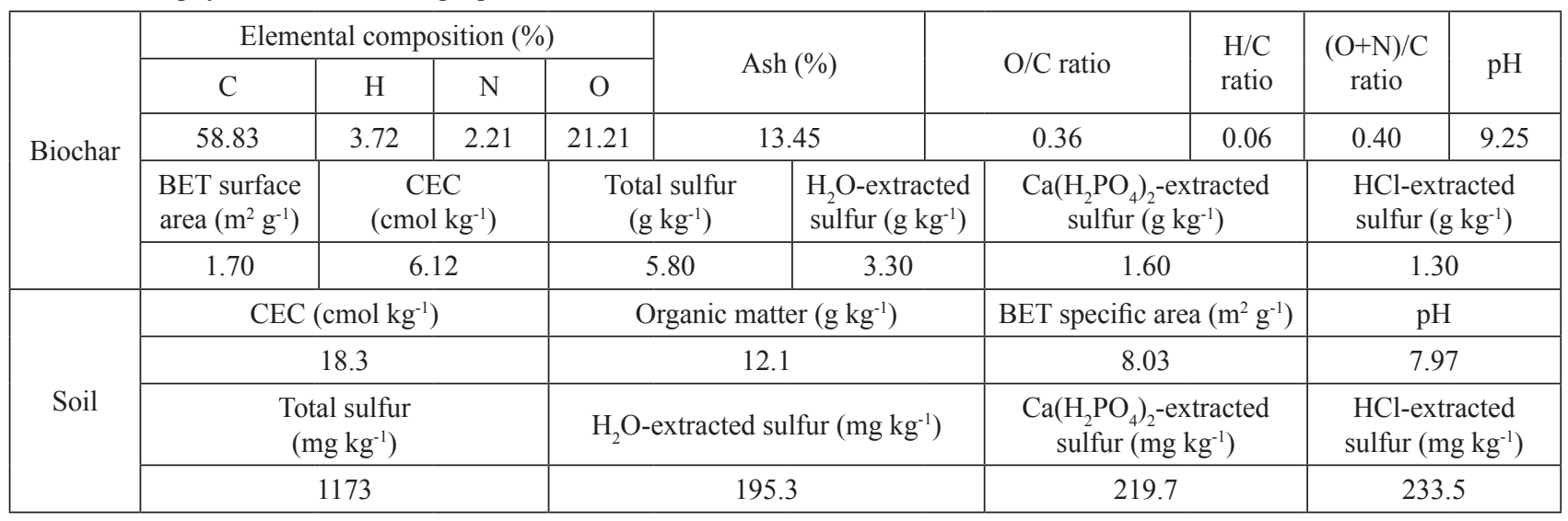

in a brown bottle. The basic physical and chemical properties of the biochar are listed in Table 1.

The soil (Calcids) was collected from top soil $(0-20 \mathrm{~cm})$ of a farm land in Yuzhong County in Lanzhou City, China. The leaves, branches and other debris in soil were removed. The soil was air-dried and passed through a 5-mm sieve. The physical and chemical properties of the soil are listed in Table 1.

All the chemicals were of analytical grade and deionized water was used throughout the experiments.

Corn (Zea mays L.) seeds were obtained from the Beijing Kenfeng Longyuan Seed Industry Technology Co., Ltd., in China.

\section{Pot Experiments}

The biochar was added to $5 \mathrm{~kg}$ of the soil at the rate of $0,0.5,1,2$ or $5 \%$ respectively and mixed thoroughly. Then, the soil or soil with biochar was placed into a plastic pot $(130 \mathrm{~mm} \times 116 \mathrm{~mm})$. Exogenous sulfur as sulfate solution $\left(\mathrm{Na}_{2} \mathrm{SO}_{4}\right)$ was added to the pot at a low level (0 mg S $\mathrm{kg}^{-1}$ soil), a moderate level (50 mg S kg-1 soil) or a high level (100 mg S kg-1 soil). Each pot received base fertilizers as following: $125 \mathrm{mg} \mathrm{K}\left(\mathrm{KH}_{2} \mathrm{PO}_{4}\right), 110 \mathrm{mg} \mathrm{N}$ (urea), $100 \mathrm{mg} \mathrm{P}$ $\left(\mathrm{KH}_{2} \mathrm{PO}_{4}\right), 10 \mathrm{mg} \mathrm{Mn}\left(\mathrm{MnCl}_{2}\right), 2 \mathrm{mg} \mathrm{Zn}\left(\mathrm{ZnCl}_{2}\right)$, $1 \mathrm{mg} \mathrm{Cu}\left(\mathrm{CuCl}_{2} \cdot 2 \mathrm{H}_{2} \mathrm{O}\right), 1 \mathrm{mg} \mathrm{B}\left(\mathrm{H}_{3} \mathrm{BO}_{3}\right), 50 \mathrm{mg} \mathrm{Mg}$ $\left(\mathrm{MgCl}_{2} \cdot 6 \mathrm{H}_{2} \mathrm{O}\right)$, and $0.1 \mathrm{mg} \mathrm{Mo}\left(\mathrm{Na}_{2} \mathrm{MoO}_{4} \cdot 2 \mathrm{H}_{2} \mathrm{O}\right)$ per $\mathrm{kg}$ of soil [26]. The fertilizers were added to the soil or soil with biochar as a solution and were mixed thoroughly prior to potting. Each treatment was set as three parallel tests.

The pot experiments were carried out under greenhouse conditions (average temperature of $20^{\circ} \mathrm{C}$ and average humidity of $40 \%$ ). Each pot received 6 corn seeds. After 1 week of germination, three seedlings were retained. During growth, $70-85 \%$ of soil moisture was maintained and necessary pest control was performed. The plants were harvested after 60 days of growth, the plant height and fresh weight were determined and the chlorophyll content in the leaves was measured. The harvested corn was washed with deionized water to remove the soil and then dried in an oven at $80^{\circ} \mathrm{C}$ for
$48 \mathrm{~h}$. The dry weight of plant was determined. Then, the leaves and roots were cut; after crushing and digestion, the total sulfur content was determined. After sampling a small amount of soil in the rhizosphere, the $\mathrm{pH}$ value, catalase, urease and sucrase activity, as well as the contents of inorganic sulfur and total sulfur in soil were determined.

\section{Analytical Methods}

For biochar sample, the $\mathrm{pH}$ value was measured using a $\mathrm{pH}$ meter (PHS-3C, Shanghai Electronic and Scientific Instrument Co., China) with 1: 2.5 (w/w) suspension of biochar in deionized water; the cation exchange capacity (CEC) was determined according to the calcium acetate method (China NY/T1121.52006); the element composition of $\mathrm{C}, \mathrm{H}, \mathrm{O}, \mathrm{N}$ and ash in biochar was determined with an elemental analyzer (Vario EL, Elementar, Germany), and the atomic ratios were calculated; and the specific surface area was obtained from Brunauer-Emmett-Teller (BET) $\mathrm{N}_{2}$ adsorption at $77 \mathrm{~K}$ using a Quantachrome Autosorb-1 (Quantachrome, USA). The total sulphur in biochar was determined with nitric and perchloric acids (2:1) digestion and indirect atomic absorption spectrometry (SP-3520AAC2T1, Shanghai Spectrum Co., Ltd., China) [34]. Three step extraction processes were utilized to classify inorganic sulfur in biochar: i) extraction with water ( $\mathrm{H}_{2} \mathrm{O}$-sulfur); (ii) extraction with $0.1 \mathrm{~mol} \mathrm{~L}^{-1}$ $\mathrm{Ca}\left(\mathrm{H}_{2} \mathrm{PO}_{4}\right)_{2} \quad\left(\mathrm{Ca}\left(\mathrm{H}_{2} \mathrm{PO}_{4}\right)_{2}\right.$-sulfur $)$; (iii) extraction with $0.1 \mathrm{~mol} \mathrm{~L}^{-1} \mathrm{HCl}$ (HCl-sulfur). The extraction solution was filtered through a $0.45 \mu \mathrm{m}$ membrane and the sulfate $\left(\mathrm{SO}_{4}^{2-}\right)$ amount in the filtrate was determined by indirect atomic absorption spectrometry.

For soil sample, the $\mathrm{pH}$ value was measured on the $\mathrm{pH}$ meter with 1: $20(\mathrm{w} / \mathrm{w})$ suspension of soil in deionized water; the CEC was determined according to the calcium acetate method (China NY/T1121.5-2006); the content of soil organic matter was determined by potassium dichromate oxidation-spectrophotometry (China HJ 615-2011) on a UV-1800 spectrophotometer (Shanghai Spectrum Instrument Co. Ltd., China); Soil urease activity was determined by the colorimetric 
Table 2. Effects of biochar addition on corn plant height, fresh and dry weight, and chlorophyll content in leaves with different sulfate addition levels.

\begin{tabular}{|c|c|c|c|c|c|c|}
\hline \multirow{2}{*}{ Index } & \multirow{2}{*}{ Sulfur level } & \multicolumn{5}{|c|}{ Biochar addition rate $(\%)$} \\
\hline & & 0 & 0.5 & 1 & 2 & 5 \\
\hline \multirow{3}{*}{ Plant height $(\mathrm{cm})$} & Low & $99.5 \pm 4.29 \mathrm{cb}$ & $87.9 \pm 4.54 \mathrm{c}$ & $111.1 \pm 5.05 b$ & $128.8 \pm 3.17 \mathrm{a}$ & $67.3 \pm 11.70 \mathrm{~d}$ \\
\hline & Moderate & $119.6 \pm 3.42 \mathrm{c}$ & $114.1 \pm 0.96 \mathrm{c}$ & $129.7 \pm 5.14 b$ & $142.2 \pm 3.69 \mathrm{a}$ & $98.6 \pm 2.14 d$ \\
\hline & High & $107.8 \pm 2.52 \mathrm{c}$ & $119.7 \pm 2.6 \mathrm{cb}$ & $123.8 \pm 0.19 \mathrm{ba}$ & $132.6 \pm 0.25 \mathrm{a}$ & $90.5 \pm 3.34 \mathrm{~d}$ \\
\hline \multirow{3}{*}{ Fresh weight (g) } & Low & $692.0 \pm 9.20 \mathrm{~d}$ & $791.6 \pm 5.59 \mathrm{c}$ & $892.4 \pm 4.21 b$ & $941.2 \pm 7.81 \mathrm{a}$ & $435.2 \pm 12.55 \mathrm{e}$ \\
\hline & Moderate & $888.0 \pm 8.08 \mathrm{~d}$ & $934.4 \pm 4.03 \mathrm{c}$ & $979.2 \pm 6.32 b$ & $1035.7 \pm 13.7 \mathrm{a}$ & $801.2 \pm 8.86 \mathrm{e}$ \\
\hline & High & $759.1 \pm 8.98 \mathrm{c}$ & $764.2 \pm 10.46 \mathrm{c}$ & $947.8 \pm 8.98 b$ & $990.9 \pm 8.74 \mathrm{a}$ & $697.5 \pm 7.59 \mathrm{~d}$ \\
\hline \multirow{3}{*}{ Dry weight (g) } & Low & $241.5 \pm 1.35 \mathrm{~d}$ & $302.6 \pm 2.9 \mathrm{c}$ & $338.6 \pm 2.89 b$ & $364.1 \pm 3.21 \mathrm{a}$ & $176.2 \pm 0.85 \mathrm{e}$ \\
\hline & Moderate & $332.7 \pm 2.00 \mathrm{c}$ & $345.7 \pm 3.95 b$ & $369.7 \pm 4.66 b$ & $419.2 \pm 1.44 \mathrm{a}$ & $303.3 \pm 3.38 \mathrm{~d}$ \\
\hline & High & $293.1 \pm 2.35 c$ & $309.3 \pm 5.18 \mathrm{c}$ & $354.0 \pm 1.88 \mathrm{~b}$ & $380.1 \pm 3.6 \mathrm{a}$ & $243.5 \pm 2.65 \mathrm{~d}$ \\
\hline \multirow{3}{*}{ Chlorophyll (mg/g FW) } & Low & $0.85 \pm 0.06 \mathrm{e}$ & $0.91 \pm 0.05 d$ & $0.99 \pm 0.03 \mathrm{c}$ & $1.08 \pm 0.03 \mathrm{a}$ & $1.05 \pm 0.04 \mathrm{~b}$ \\
\hline & Moderate & $1.04 \pm 0.06 \mathrm{c}$ & $1.13 \pm 0.05 \mathrm{~b}$ & $1.13 \pm 0.06 \mathrm{~b}$ & $1.15 \pm 0.02 \mathrm{a}$ & $1.14 \pm 0.05 b$ \\
\hline & High & $0.92 \pm 0.04 \mathrm{~d}$ & $1.05 \pm 0.05 \mathrm{c}$ & $1.11 \pm 0.04 \mathrm{~b}$ & $1.14 \pm 0.05 \mathrm{a}$ & $1.1 \pm 0.05 b$ \\
\hline
\end{tabular}

method using superoxide dismutaseium phenolatesuperoxide dismutaseium hypochlorite, catalase activity by the potassium permanganate titration method and sucrase activity by the colorimetric method using 3,5-dinitrosalicylic acid. The soil sample was digested with nitric and perchloric acids (2:1) and the total sulfur in soil was determined by indirect atomic absorption spectrometry [34]. The inorganic sulfur in soil was determined using the same three step extraction processes and indirect atomic absorption spectrometry as those for biochar.

For plant sample, the chlorophyll in leaves was extracted using acetone-ethanol (V1: V2 = 1: 1) solvent and the chlorophyll content was determined using spectrophotometric method. The total sulfur in the plant was dissolved with nitric and perchloric acids (2:1) and the sulfate concentration in the digested solution was determined by indirect atomic absorption spectrometry.

\section{Data Processing}

Data were plotted using Origin 8.5, and statistical analysis was completed using SPSS 21.0. The mean and standard deviation of data were obtained by one-way ANOVA. Significant differences were analyzed by Duncan's multiple range test $(* P<0.05)$.

\section{Results and Discussion}

\section{Plant Physiological Characteristics}

For different levels of sulfate addition, the indexes of plant height, fresh and dry weight versus biochar addition rates are shown in Table 2. At the same sulfate addition level, the three indexes increase with the applied rates of biochar below $2 \%$ and sharply decrease at the rate of $5 \%$; at the same rate of biochar addition, the three indexes increase with sulfate addition from low level to moderate level and then decrease from moderate level to high level. This indicates that both biochar and sulfate addition have effects on the biomass of corn. Without exogenous sulfate addition and with biochar addition at the rate of $2 \%$, the plant height, fresh and dry weight are $128.8 \mathrm{~cm}, 941.2 \mathrm{~g}$ and $364.1 \mathrm{~g}$, which increase $29.4 \%, 36 \%$ and $50.8 \%$ respectively, compared with the control (low level sulfate- $0 \%$ biochar). Correspondingly, without biochar addition and at the moderate level of sulfate addition, the three indexes are $119.6 \mathrm{~cm}, 888.0 \mathrm{~g}$ and $332.7 \mathrm{~g}$, which increase by $20.2 \%, 28.3 \%$ and $37.8 \%$, compared with the control. These data indicate that the biomass enhancement by biochar alone with $2 \%$ addition rate is larger than that by sulfate alone at the moderate level. When the rate of biochar applied is $2 \%$ and the sulfate addition level is moderate, the plant height, fresh and dry weight reach the highest values, i.e. $142.2 \mathrm{~cm}, 1035.7 \mathrm{~g}$, and $419.2 \mathrm{~g}$, which increase by $42.9 \%, 49.7 \%$ and $73.6 \%$ respectively compared with the control.

The results above illustrate that co-application of biochar and sulfate at proper amounts can increase corn growth and biomass, which are similar to those from co-application of biochar and nitrogen, phosphorous and potassium fertilizers $[25,26,29,30]$. However, in this study, the increment percentages of biomasses by both $2 \%$ biochar and moderate level sulfate addition are less than the sum of increment percentages by $2 \%$ biochar alone and by moderate level sulfate alone. Therefore, no synergistic effect is found at the tested conditions. Faloye et al. studied the effect of maize-cob biochar 
and inorganic fertilizer (nitrogen: phosphorous: potassium $=15: 15: 15)$ on the growth of maize under drip irrigation system, in which when biochar and fertilizer were applied together, the average increase in biomass was $151 \%$, indicating a strong synergistic effect of biochar and fertilizer [27]. In that case, the increase was synergistically high due to poor soil condition (especially fertility) at the experimental site and very low biomass yield in the control pots [27].

As shown in Table 2, obvious inhibitory effects on corn growth are found when biochar addition at the rate of $5 \%$. The inhibitory effect might be caused by high $\mathrm{pH}$ values of soil due to the $5 \%$ biochar amendment, which was not conducive to the growth of corn [31]. Meanwhile, Table 2 shows that excessive amount of sulfur (high level) is not optimum for plant growth with or without the biochar amendment. It is found that excessive amount of sulfur can harm plant growth, development and metabolism and may even cause death if the sulfur levels are too high. Wang and Xu applied a certain amount of sulfuric fertilizer to soil for a winter wheat planting experiment. Their research showed that when the sulfur concentration was $40 \mathrm{mg} \mathrm{kg}^{-1}$, the growth and dry matter accumulation of winter wheat were better [35]. Accordingly, an optimum level of nitrogen fertilizer application is required to improve the growth and yield of barley. Moderate application rates could increase yield but excessively high rates could reduce test weight and yield [25].

Table 2 also reflects the influence of biochar addition on corn leaf chlorophyll content at the different sulfate addition level. At the same sulfate addition level, the chlorophyll contents of corn leaves increase firstly and then decreased with the rates of biochar addition. The chlorophyll contents reach the highest values when the rate of biochar addition is $2 \%$. The chlorophyll contents increase by $27.1 \%$ with $2 \%$ biochar alone, by $22.3 \%$ with moderate level sulfate alone, and by $35.3 \%$ with both $2 \%$ biochar and moderate level sulfate. This indicates that co-application of biochar and sulfate at proper amounts enhanced chlorophyll contents over biochar alone or sulfate alone. However, no synergistical effect of co-application of biochar and sulfate on chlorophyll content enhancement was observed. Similar results were observed by Agegnehu et al., who found that application of biochar combined with fertilizer enhanced barley leaf chlorophyll over biochar alone or mineral fertilizer alone [18]. As shown in Table 2, at the same biochar addition rate, the chlorophyll contents with moderate sulfate level were the largest. Kumar and Sidhu reported that soil sulfur deficiency would reduce the number of chloroplast [36]. As mentioned above, excessive amount of sulfate (high level) is not optimum for corn growth, which could result in decrease of chlorophyll content.

\section{Soil Properties}

As shown in Fig. 1, there are significant differences in soil $\mathrm{pH}$ values among the different biochar treatments $(P<0.05)$. With the increase of biochar addition, the soil $\mathrm{pH}$ values increased significantly. It was observed that a)

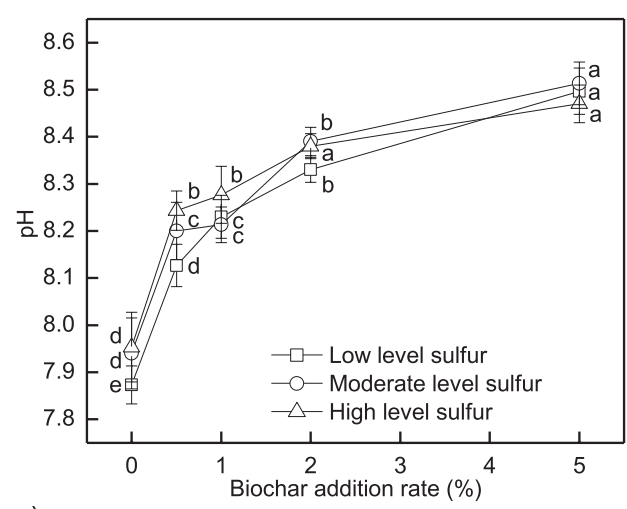

c)

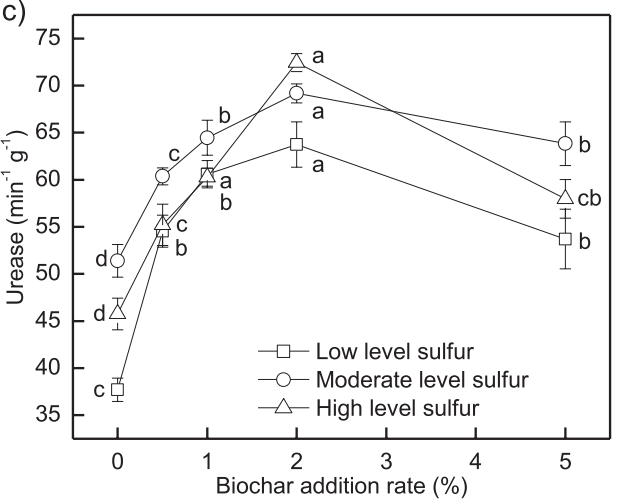

b)

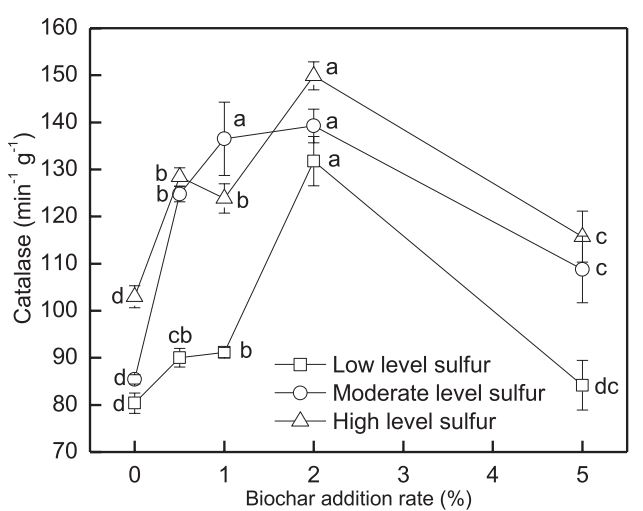

d)

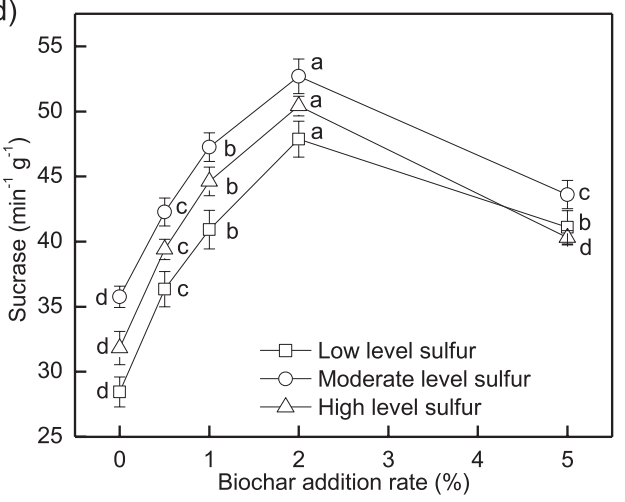

Fig. 1 Effect of biochar addition on $\mathrm{pH}$ value a), catalase b), urease c) and sucrase d) activity of soil with different sulfate addition levels. 


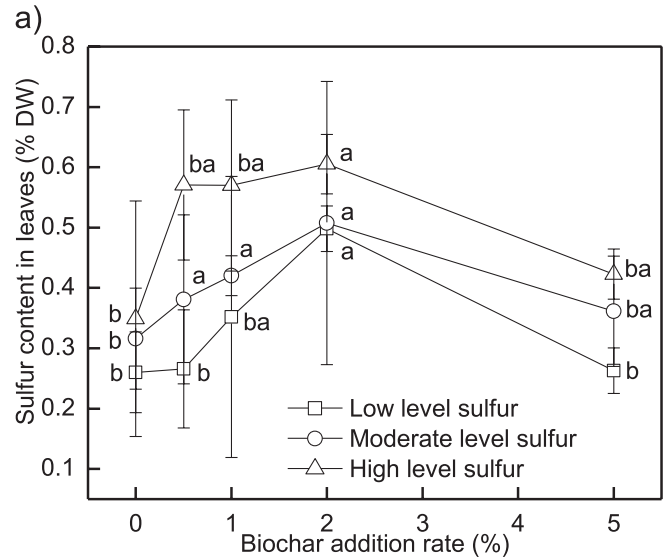

b)

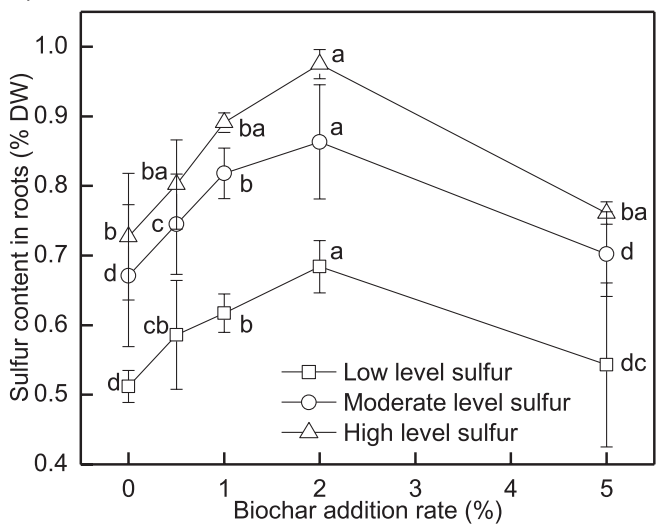

Fig. 2 Effect of biochar addition on sulfur content in leaves a) and roots b) with different sulfate addition levels.

when the rate of biochar addition is $5 \%$, the $\mathrm{pH}$ values of soil treated with low, moderate and high level of sulfate addition increase by $8 \%, 7 \%$ and $6 \%$, reaching $8.50,8.55$ and 8.47 , respectively. Comparatively, with the same biochar application, the changes in soil $\mathrm{pH}$ value by sulfate addition are not significant somewhat [37]. Soil $\mathrm{pH}$ value is an important characteristic of soils in terms of nutrient availability and plant growth. It is a traditional practice to amend acidic soils by adding lime to raise the $\mathrm{pH}$ of soil, which allows plants to grow at their maximum potential [25]. After biochar was applied to the soil, it directly affected the soil $\mathrm{pH}$ and increased the soil $\mathrm{pH}$ value [6]. Previous studies have documented that the positive effects of addition of biochar and fertilizer on yield and yield components of crop growing in acidic soils were attributed to the increment in soil $\mathrm{pH}$ by biochar amendment, which reduced soil acidity and increased level of available nitrogen, phosphorous and potassium and micronutrients [20, 29, 38]. However, Calcids soil is a calcareous soil, and the intrinsic $\mathrm{pH}$ value is larger. Our previous study showed that further increment in $\mathrm{pH}$ value after the biochar amendment into Calcids soil could lead to inhibitory effect on corn growth [31].

As shown in Fig. 1, the biochar amendment significantly affects the activity of catalase, urease and sucrase in soil, showing significant differences. At the same level of sulfate addition, the values of three enzyme activity increase initially and then decrease with the addition of biochar. When the amount of applied biochar was $2 \%$, the three enzymes were the most active and their activity increased respectively by $69 \%, 35 \%$ and $58 \%$ for catalase, by $64 \%, 63 \%$ and $46 \%$ for urease, and by $68 \%, 47 \%$ and $58 \%$ for sucrase with the low, moderate and high level of sulfate addition, compared with no biochar addition. The results indicate that a proper amount of biochar amendment could enhance the soil microorganism activity, which was closely related to the soil enzyme activity [6]. Analogously, the positive effects of corn stalk biochar addition on the calcareous soil enzymes (catalase, dehydrogenase, cellulose, invertase, and protease) were much greater at $1 \%$ than $0.5 \%$ application rates, where the change in enzyme activity with biochar addition primarily attributed to the change in soil microbial biomass [39]. Acidic soil properties could be improved by biochar and lime, where biochar had better amelioration effects on increases of soil $\mathrm{pH}$, soil respiration and microbial metabolic quotient, activities of soil urease, invertase, catalase and cellulose [40]. However, when the biochar was added at $5 \%$ rate into the soil, all the three enzyme activity decreased compare with $2 \%$ application rate, which could be attributed a higher $\mathrm{pH}$ values by biochar amendment. It is reported that $\mathrm{pH}$ values of soil ranging from 3.5-8.5, especially from 5.5-8.5, are optimum for microorganism activity [41].

\section{Sulfur Availability}

Fig. 2 shows the plots of sulfur fraction in dry leaves and roots versus the rates of biochar addition at the different levels of sulfate addition. At the same level of sulfate addition, the sulfur contents increase initially and then decrease with the addition of biochar. When

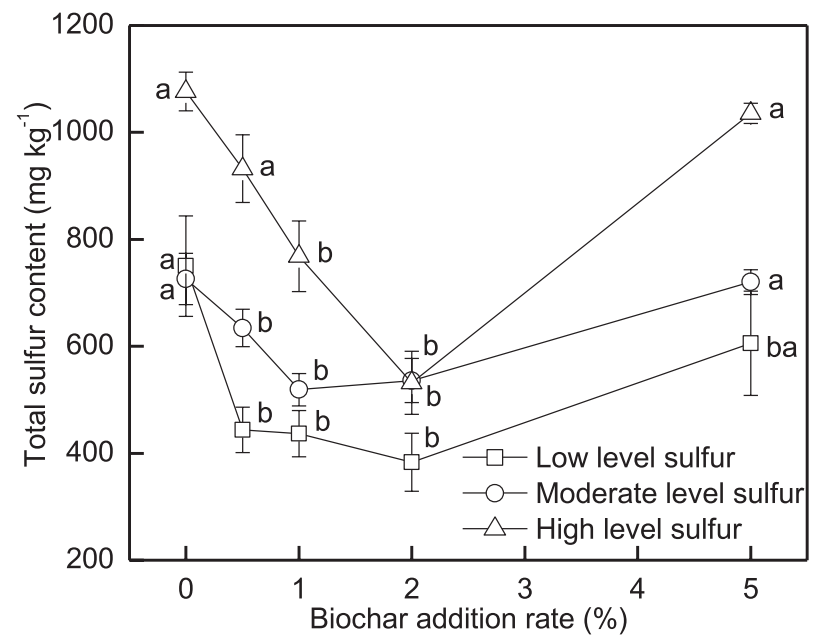

Fig. 3 Effect of biochar addition on total sulfur content in soil with different sulfate addition levels. 
Table 3. Effect of biochar addition on $\mathrm{H}_{2} \mathrm{O}-, \mathrm{Ca}\left(\mathrm{H}_{2} \mathrm{PO}_{4}\right)_{2}$ - and $\mathrm{HCl}$-extracted sulfur contents in rhizosphere soil with different sulfate addition levels.

\begin{tabular}{|c|c|c|c|c|c|c|}
\hline \multirow{2}{*}{ Extraction process } & \multirow{2}{*}{ Sulfur level } & \multicolumn{5}{|c|}{ Biochar addition rate (\%) } \\
\cline { 2 - 7 } & Low & $157.47 \pm 3.93 \mathrm{a}$ & $144.42 \pm 3.77 \mathrm{~b}$ & $135.62 \pm 2.18 \mathrm{c}$ & $124.32 \pm 4.35 \mathrm{~d}$ & $148.47 \pm 2.41 \mathrm{~b}$ \\
\hline \multirow{3}{*}{$\begin{array}{c}\mathrm{H}_{2} \mathrm{O}- \\
\left(\mathrm{mg} \mathrm{kg}^{-1}\right)\end{array}$} & Moderate & $179.48 \pm 2.23 \mathrm{a}$ & $160.70 \pm 3.16 \mathrm{~b}$ & $143.15 \pm 2.17 \mathrm{~d}$ & $134.93 \pm 2.17 \mathrm{e}$ & $152.79 \pm 1.41 \mathrm{c}$ \\
\cline { 2 - 7 } & High & $189.92 \pm 1.82 \mathrm{a}$ & $165.12 \pm 2.51 \mathrm{~b}$ & $144.09 \pm 2.98 \mathrm{c}$ & $143.12 \pm 2.76 \mathrm{c}$ & $162.84 \pm 4.15 \mathrm{~b}$ \\
\hline \multirow{3}{*}{$\begin{array}{c}\mathrm{Ca}\left(\mathrm{H}_{2} \mathrm{PO}_{4}\right)_{2}^{-} \\
\left(\mathrm{mg} \mathrm{kg}^{-1}\right)\end{array}$} & Low & $179.44 \pm 2.12 \mathrm{a}$ & $161.26 \pm 1.9 \mathrm{cb}$ & $157.4 \pm 0.24 \mathrm{c}$ & $146.74 \pm 2.99 \mathrm{~d}$ & $164.36 \pm 3.8 \mathrm{~b}$ \\
\cline { 2 - 7 } & Moderate & $204.93 \pm 2.18 \mathrm{a}$ & $184.49 \pm 2.78 \mathrm{~b}$ & $180.99 \pm 1.51 \mathrm{~b}$ & $167.28 \pm 2.07 \mathrm{c}$ & $181.07 \pm 2.31 \mathrm{~b}$ \\
\cline { 2 - 7 } & High & $224.59 \pm 3.07 \mathrm{a}$ & $199.38 \pm 0.95 \mathrm{~b}$ & $190.87 \pm 1.35 \mathrm{c}$ & $174.17 \pm 3.19 \mathrm{~d}$ & $203.69 \pm 3.63 \mathrm{~b}$ \\
\hline \multirow{2}{*}{$\begin{array}{c}\mathrm{HCl}- \\
\left(\mathrm{mg} \mathrm{kg}{ }^{-1}\right)\end{array}$} & Moderate & $218.15 \pm 3.1 \mathrm{a}$ & $191.52 \pm 1.05 \mathrm{c}$ & $181.25 \pm 2.45 \mathrm{~d}$ & $173.66 \pm 3.48 \mathrm{e}$ & $197.16 \pm 3.47 \mathrm{~b}$ \\
\cline { 2 - 7 } & High & $229.55 \pm 1.85 \mathrm{a}$ & $215.26 \pm 2.01 \mathrm{c}$ & $209.37 \pm 3.74 \mathrm{~d}$ & $202.56 \pm 0.98 \mathrm{e}$ & $221.14 \pm 1.89 \mathrm{~b}$ \\
\hline
\end{tabular}

the biochar was applied at $2 \%$ and the sulfate addition was applied with the low, moderate and high level, the sulfur contents were the highest and increased by $92 \%, 61 \%$ and $73 \%$ in the leaves and by $24 \%, 29 \%$ and $34 \%$ in roots compared with no biochar addition. When biochar was applied at $5 \%$, the sulfur content in the corn leaves and roots significantly decreased compared with at $2 \%$. This indicates that the proper amount of biochar could increase the uptake of sulfur by corn leaves and roots. At the same rate of biochar addition, the sulfur content in the corn leaves and roots increased at large with increasing sulfate amendment level. The accumulation of sulfur in corn plants is mainly affected by the physical and chemical properties of the soil and the total sulfur content in the soil [42]. Thus, the higher the concentration of exogenous sulfur is, the greater the degree of sulfur enrichment in the corn leaves and roots. Agegnehu et al. observed the application of nitrogen fertilizer resulted in significant responses of nitrogen uptake of barley, where there were significant linear responses for grain and straw nitrogen concentration [26].

Fig. 3 shows the plots of total sulfur contents in rhizosphere soil versus the biochar addition rates with the different level of sulfate addition. For the same level of sulfate addition, the total sulfur content initially decreased and then increased with biochar addition. The total sulfur contents were the lowest when the applied biochar amounted to $2 \%$, where the total sulfur content reduction rates were $51 \%, 29 \%$ and $49 \%$, respectively for the three sulfate treatment levels, compared with no biochar addition. With the same rate of biochar applied, the total sulfur content increased with sulfate addition in the order of low level $<$ moderate level $<$ high level. Table 3 shows the inorganic sulfur $\left(\mathrm{H}_{2} \mathrm{O}-, \mathrm{Ca}\left(\mathrm{H}_{2} \mathrm{PO}_{4}\right)_{2}\right.$ and $\mathrm{HCl}$-extracted sulfur) content in rhizosphere soil versus the biochar addition rates with the different level of sulfate addition. For the same level of biochar treatment, the fractions of inorganic sulfur are in the order of $\mathrm{H}_{2} \mathrm{O}-,<\mathrm{Ca}\left(\mathrm{H}_{2} \mathrm{PO}_{4}\right)_{2}-<\mathrm{HCl}$-extracted sulfur. For the same sulfate treatment levels, the three sulfur fraction contents decreased initially with increasing biochar applications but increased while the application rate was larger than $2 \%$. The results show that the application of biochar resulted in significant responses of sulfur accumulation of corn to decrease in the inorganic sulfur and total sulfur content in soil, no matter whether sulfur was applied or not.

\section{Conclusions}

Increasing the biochar amendment rate $(0.5,1$ and $2 \%$ ) resulted in significant enhancement of the physiological indexes including plant height, fresh and dry weight, and chlorophyll content in leaves but a further increasing rate up to $5 \%$ led to significant decrease in these indexes. Sulfate amendment at moderate level was obviously beneficially to plant height, fresh and dry weight, and chlorophyll content. With the biochar amendment rate increasing, the $\mathrm{pH}$ values of soil were significantly increased in succession, reaching about 8.50 at the rate of $5 \%$. The variation pattern of the enzyme (catalase, urease and sucrase) activity in soil versus the biochar amendment rate was similar to those of the physiological indexes. The sulfur contents in leaves and roots increased initially and then decreased with the biochar amendment, where the highest contents were obtained at the rate of $2 \%$ and high level. The decreases of inorganic sulfur and total sulfur contents in soil with biochar addition rates well responded to accumulation of corn in leaves and roots. Too high $\mathrm{pH}$ values of soil due to $5 \%$ biochar amendment were to the disadvantage of plant growth and microorganism activity in soil. The results show that co-application of biochar and exogenous sulfur with proper amount could improve growth and sulfur phytoavailability of plant in calcareous soil. 


\section{Acknowledgements}

This research was financially supported by the National Natural Science Foundation of China $(51766008,21467013,21167007)$.

\section{Conflict of Interest}

The authors declare no conflict of interest.

\section{References}

1. FROSSARD E., BÜNEMANN E.K., OBERSON A., KERTESZ M.A. Phosphorus and Sulfur in Soil, CRC Press: Boca Raton, United Kingdom, 2012.

2. ZHANG J., CHI F., ZHOU B., WEI D., KUANG E. Sulfur bioavailability of black soil in northeast China. Acta Agr. Scand., 63, 172, 2014.

3. AGHAJANZADEH T., HAWKESFORD M., KOK L. Atmospheric $\mathrm{H}_{2} \mathrm{~S}$ and $\mathrm{SO}_{2}$ as sulfur sources for Brassica juncea and Brassica rapa: Regulation of sulfur uptake and assimilation. J. Environ. Exp. Bot., 124, 1, 2016.

4. AGHAJANZADEH T., HAWKESFORD M., KOK L. The significance of glucosinolates for sulfur storage in Brassicaceae seedlings. Front. Plant Sci., 5, 1, 2014.

5. MITCHELL M., DRISCOLL C., MCHALE P., ROY K., ZHENG D. Lake/watershed sulfur budgets and their response to decreases in atmospheric sulfur deposition: watershed and climate controls. Hydrol. Process, 27, 710, 2013.

6. LEHMANN J., JOSEPH S. Biochar for Environmental Management: Science, Technology and Implementation, Routledge: Abingdon, United Kingdom, 2015.

7. EL-NAGGAR A., EL-NAGGAR A.H., SHAHEEN S.M., SARKAR B., CHANG S.X., TSANG D.C.W., RINKLEBE J., OK Y.S. Biochar composition-dependent impacts on soil nutrient release, carbon mineralization, and potential environmental risk: A review. J. Environ. Manage., 241, 458, 2019.

8. ROSA J.M., SÁNCHEZ-MARTÍN Á.M., CAMPOS P., MILLER A.Z. Effect of pyrolysis conditions on the total contents of polycyclic aromatic hydrocarbons in biochars produced from organic residues: Assessment of their hazard potential. Sci. Total Environ., 667, 578, 2019.

9. WANG J., XIA K., WAIGI M.G., GAO Y., ODINGA E.S., LING W., LIU J. Application of biochar to soils may result in plant contamination and human cancer risk due to exposure of polycyclic aromatic hydrocarbons. Environ. Inter., 121, 169, 2018.

10. SHEN X., ZENG J., ZHANG D., WANG F., LI Y., YI W. Effect of pyrolysis temperature on characteristics, chemical speciation and environmental risk of $\mathrm{Cr}, \mathrm{Mn}, \mathrm{Cu}$, and $\mathrm{Zn}$ in biochars derived from pig manure. Sci. Total Environ., 704, 135283, 2020.

11. JIN J., WANG M., CAO Y., WU S., LIANG P., LI Y., ZHANG J., ZHANG J., WONG M.H., SHAN S., CHRISTIE P. Cumulative effects of bamboo sawdust addition on pyrolysis of sewage sludge: Biochar properties and environmental risk from metals. Bioresour. Technol., 228, 218, 2017.

12. WANG S., SHI R., LI H., LI Y., XU Y., HAN Z. Effect of terminal temperature on the morphology and potentially toxic metals concentrations of biochars derived from paper and kitchen waste. Waste Manage., 118, 445, 2020.

13. ZHANG P, ZHANG X., LI Y., HAN L. Influence of pyrolysis temperature on chemical speciation, leaching ability, and environmental risk of heavy metals in biochar derived from cow manure. Bioresour. Technol., 302, 122850, 2020.

14. JIN J., LI Y., ZHANG J., WU S., CAO Y., LIANG P., ZHANG J., WONG M.H., WANG M., SHAN S., CHRISTIE $\mathrm{P}$. Influence of pyrolysis temperature on properties and environmental safety of heavy metals in biochars derived from municipal sewage sludge. J. Hazard. Mater., 320, 417, 2016.

15. PANDIT N.R., MULDER J., HALE S.E., MARTINSEN V., SCHMIDT H.P., CORNELISSEN G. Biochar improves maize growth by alleviation of nutrient stress in a moderately acidic low-input. Sci. Total Environ., 625, 1380, 2018.

16. SINGH C., TIWARI S., GUPTA V.K., SINGH J.S. The effect of rice husk biochar on soil nutrient status, microbial biomass and paddy productivity of nutrient poor agriculture soils. Catena, 171, 485, 2018.

17. SONG D., XI X., ZHENG Q., LIANG G., ZHOU W., WANG X. Soil nutrient and microbial activity responses to two years after maize straw biochar application in a calcareous soil. Ecotox. Environ. Safe., 180, 348, 2019.

18. WANG H., ZHENG H., JIANG Z., DAI Y., LIU G., CHEN L., LUO X., LIU M., WANG Z. Efficacies of biochar and biochar-based amendment on vegetable yield and nitrogen utilization in four consecutive planting seasons. Sci. Total Environ., 593-594, 124, 2017.

19. BORNO ML, EDUAH JO, MULLER-STOVER DS, LIU F Effect of different biochars on phosphorus (P) dynamics in the rhizosphere of Zea mays L. (maize). Plant Soil, 431, 257,2018

20. GAO S., DELUCA T.H., CLEVELAND C.C. Biochar additions alter phosphorus and nitrogen availability in agricultural ecosystems: a meta-analysis. Sci. Total Environ., 654, 463, 2019.

21. HONG C., SU Y., LU S.G. Phosphorus availability changes in acidic soils amended with biochar, fly ash, and lime determined by diffusive gradients in thin films (DGT) technique. Environ. Sci. Pollut. Res., 25, 30547, 2018.

22. ZHOU K., SUI Y.Y., XU X., ZHANG J.Y., CHEN Y.M., HOU M., JIAO X.G. The effects of biochar addition on phosphorus transfer and water utilization efficiency in a vegetable field in Northeast China. Agr. Water Manage., 210, 324, 2018.

23. LIU M., CHE Y., WANG L., ZHAO Z., ZHANG Y., WEI L., XIAO Y. Rice straw biochar and phosphorus inputs have more positive effects on the yield and nutrient uptake of Lolium multiflorum than arbuscular mycorrhizal fungi in acidic Cd-contaminated soils. Chemosphere, 235, 32, 2019.

24. GRIFFIN D.E., WANG D., PARIKH S.J., SCOW K.M. Short-lived effects of walnut shell biochar on soils and crop yields in a long-term field experiment. Agr. Ecosyst. Environ., 236, 21, 2017.

25. AGEGNEHU G., NELSON P.N., BIRD M.I. Crop yield, plant nutrient uptake and soil physicochemical properties under organic soil amendments and nitrogen fertilization on Nitisols. Soil Till. Res., 160, 1, 2016.

26. AGEGNEHU G., NELSON P.N., BIRD M.I. The effects of biochar, compost and their mixture and nitrogen fertilizer on yield and nitrogen use efficiency of barley 
grown on a Nitisol in the highlands of Ethiopia. Sci. Total Environ., 569-570, 869, 2016.

27. FALOYE O.T., ALATISE M.O., AJAYIA A.E., EWULO B.S. Synergistic effects of biochar and inorganic fertiliser on maize (Zea mays) yield in an alfisol under drip irrigation. Soil Till. Res., 174, 214, 2017.

28. LUSIBA S., ODHIAMBO J., OGOLA J. Effect of biochar and phosphorus fertilizer application on soil fertility: soil physical and chemical properties. Arch. Agron. Soil Sci., 63, 477, 2017.

29. OLADELE S.O., ADEYEMO A.J., AWODUN M.A. Influence of rice husk biochar and inorganic fertilizer on soil nutrients availability and rain-fed rice yield in two contrasting soils. Geoderma, 336, 1, 2019.

30. SADAF J., SHAH G.A., SHAHZAD K., ALI N., SHAHID M., ALI S., HUSSAIN R.A., AHMED Z.I., TRAORE B., ISMAIL I.M.I., RASHID M.I. Improvements in wheat productivity and soil quality can accomplish by coapplication of biochars and chemical fertilizers. Sci. Total Environ., 607-608, 715, 2017.

31. ZHAO B., XU R., MA F., LI Y., WANG L. Effects of biochars derived from chicken manure and rape straw on speciation and phytoavailability of $\mathrm{Cd}$ to maize in artificially contaminated loess soil. J. Environ. Manage., 184, 569, 2016.

32. ZHAO B., NAN X., XU H., ZHANG T., MA F. Sulfate sorption on rape (Brassica campestris L.) straw biochar, loess soil and a biochar-soil mixture. J. Environ. Manage., 201, 309, 2017.

33. CONG Y., JIA L., ZHENG Y. Influence of sulfur supply on the iron accumulation in rice plants. Commun. Soil Sci. Plant Anal., 45, 1149, 2014.
34. CHATTARAJ S., DAS A.K. Indirect atomic absorption spectrometric determination of sulfate in human blood serum. Analyst, 117, 413, 1992.

35. WANG G., XU Z. The effects of biochar on germination and growth of wheat in different saline-alkali soil. Asian Agr. Res., 5, 116, 2013.

36. KUMAR D., SIDHU S.S. Response of soybean to soil applied sulfur and boron in a calcareous soil. J. Plant Nutr., 36, 1795, 2013

37. ZHANG M., GU G., WANG Y. Degradation characteristic of different biochar materials in soil environments. J. Zhejiang Univ., 38, 329, 2012.

38. PRENDERGAST-MILLER M., DUVALL M., SOHI S. Biochar-root interactions are mediated by biochar nutrient content and impacts on soil nutrient availability. Europ. J. Soil Sci., 65, 173, 2014.

39. KHADEM A., RAIESI F. Influence of biochar on potential enzyme activities in two calcareous soils of contrasting texture. Geoderma, 308, 149, 2017.

40. WU S., ZHANG Y., TAN Q., SUN X., WEI W., HU C. Biochar is superior to lime in improving acidic soil properties and fruit quality of Satsuma mandarin. Sci. Total Environ., 714, 136722, 2020.

41. HUANG Q., LIN Q., XU J. Soil Biochemistry, High Education Press: Beijing, China, 2015

42. LAIRD D., FLEMING P., WANG B., HORTON R., KARLEN D. Biochar impact on nutrient leaching from a Midwestern agricultural soil. Geoderma, 158, 436, 2010. 
